2. COLES, V.E. 1938. Studies of the life history of the Turkey Vulture (Cathartes aura septentrionalis, Wied). Ph.D. thesis, Cornell University, Ithaca, NY.

3. HOUSTON, C.S. 2004. Osprey's second trip to Costa Rica. Blue Jay 62:214-215.

4. HOUSTON, C.S. and K.I. FUNG. 1999. Saskatchewan's first Swainson's Hawk with satellite radio. Blue Jay 57:69-72.

5. HOUSTON, C.S., G.L. HOLROYD, B. TERRY, M. BLOM, and M.J. STOFFEL. 2007. Tracking Saskatchewan nestling Turkey Vultures. Blue Jay 65:201-207.

6. HOUSTON, C.S. and M. MARTELL. 2002. Speedy migration: Saskatchewan's first Osprey satellite transmitter. Blue Jay 60:74-79.
7. KIRK, D.A., and M.J. MOSSMAN. 1998. Turkey Vulture (Cathartes aura). Birds of North America, No. 339 .

8. MICROWAVE TELEMETRY, INC. 2004. Solar PTT-100 Field Manual. Microwave Telemetry, Inc. Columbia, MD.

9. MCINTYRE, C.L., D.C. DOUGLAS, and M.W. COLLOPY. 2008. Movements of Golden Eagles (Aquila chrysaetos) from Interior Alaska during their first year of independence. Auk 125:214224.

10. SCHMUTZ, J.K., C.S. HOUSTON and G.L. HOLROYD. 1996. Southward migration of Swainson's Hawks: over $10,000 \mathrm{~km}$ in 54 days. Blue Jay 54:70-76.

\title{
EASTERN WOOD-PEWEE NEST IN SOUTHEASTERN SASKATCHEWAN
}

\author{
BOB LUTERBACH, 2109 Grant Road, Regina, SK, S4S 5C9
}

On the morning of 21 June 2008, I carefully identified a female Eastern Wood-Pewee building a nest at a former provincial picnic site in the Souris Valley along Highway \# 9. It was hovering to pick dry tops of brome grass (Bromus sp.) and then returned to integrate this material into the rim of the nearly completed nest. The nest was 'saddled' on the larger branch of a large Green Ash (Fraxinus pensylvanica) within a mature grove of Box Elder (Acer negundo) and American Elm (Ulmus americanus) with an open understory. The male called sporadically nearby.

These were two of five Eastern WoodPewees recorded that day along the route from Roche Percee to Hwy \# 9. I saw another pair interact at the former Roche Percee Provincial Recreation Site and a single bird calling $5.5 \mathrm{~km}$ to the east at Longney's Crossing.

This species is a resident in smaller numbers in the riparian areas along the Souris River including the specific area of this nest. Other general areas where I and others have observed this species include Moose Mountain Provincial Park, the eastern Qu'Appelle Valley, Good Spirit Provincial Park and Duck Mountain Provincial Park. There have also been scattered reports from several other locations.

Alan R. Smith describes the Eastern Wood-Pewee as 'a rare but regular summer resident in mature deciduous forests' mainly in the Southeastern area. ${ }^{2}$ Although it has long been accepted as a possible/probable breeding species, this is apparently the first nest record of a species that was first observed in Saskatchewan by Ernest Thompson Seton at Runnymede on 14 June $1884 .^{1}$

1. HOUSTON, C.S. 1980.(Introduction to) Ernest Thompson Seton in Manitoba 1882-1892. Manitoba Naturalist Society, Winnipeg.

2. SMITH, A. R. 1996. Atlas of Saskatchewan Birds. Special Publication \# 22. Saskatchewan Natural History Society, Regina SK. 


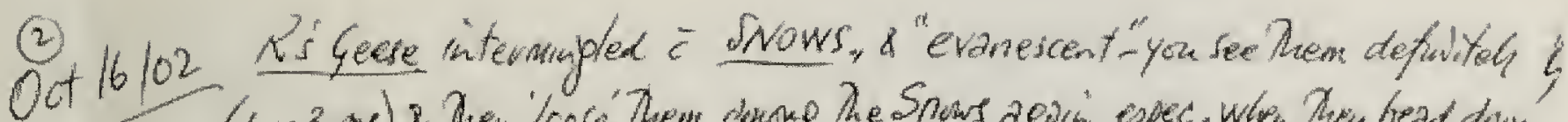

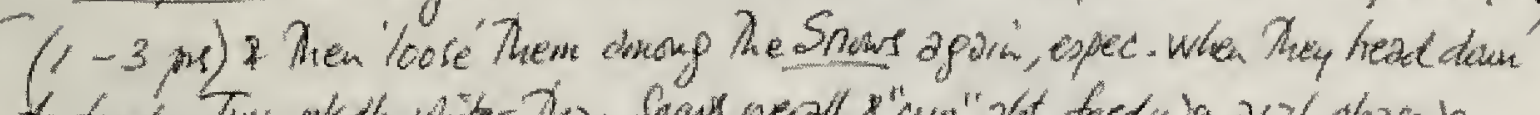

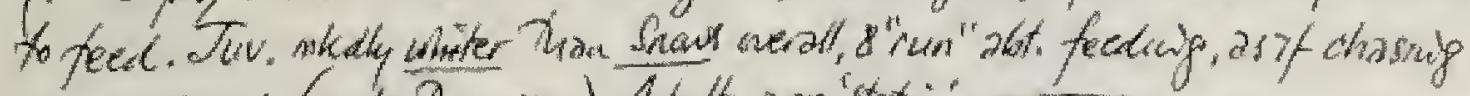
runnsing insects prisybe they were). Adatts nume 'static

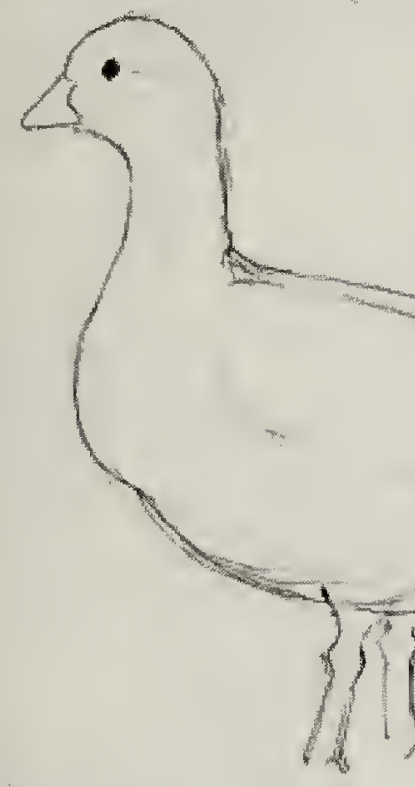

Rosp' Geeje adutts sudther 8 "baby"haded".

Tuveniles are quite white overall

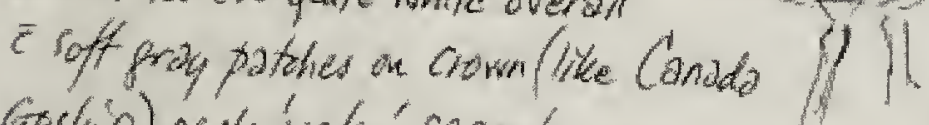
Gosing) neck, yoke', scapuras.

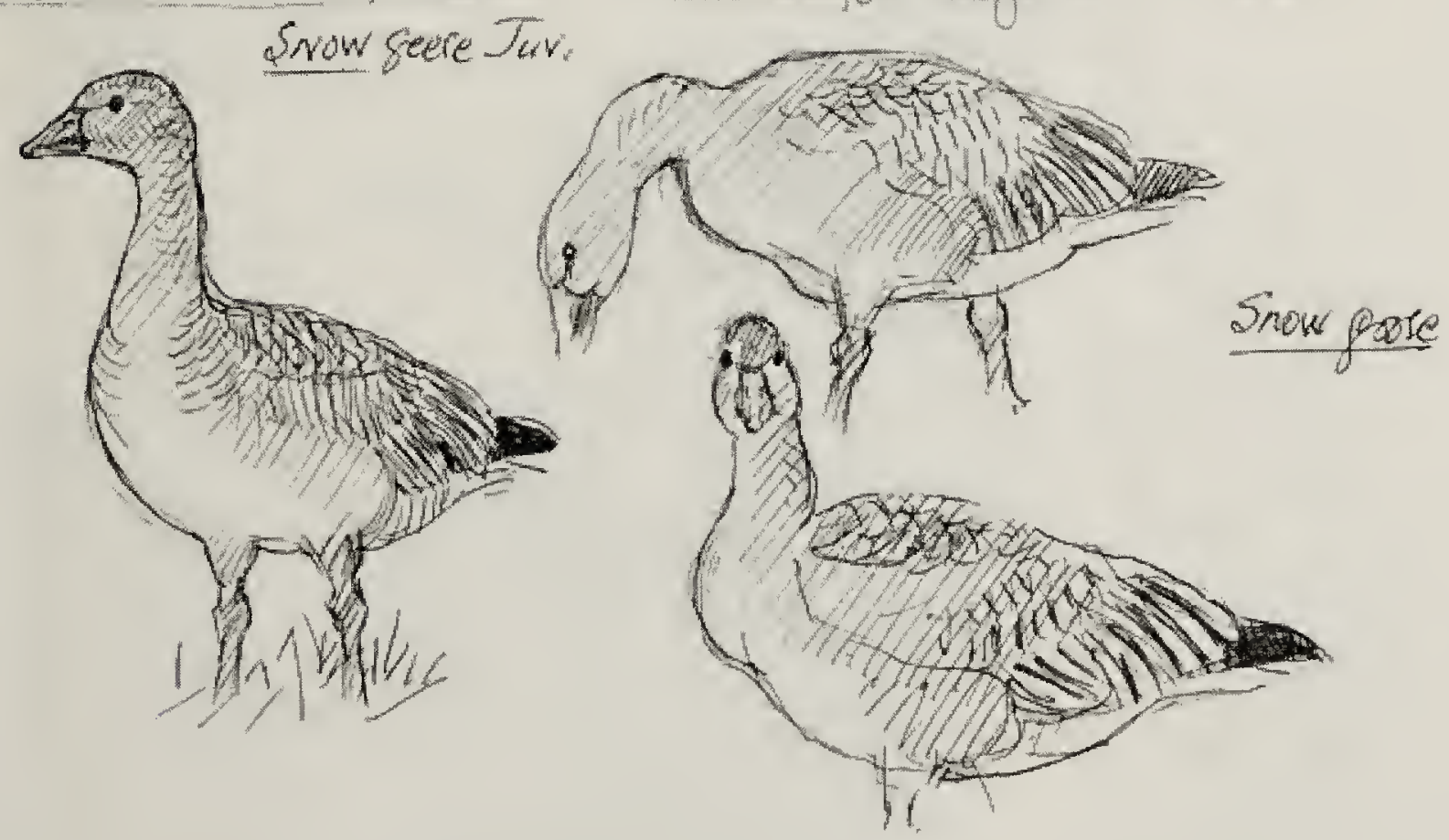




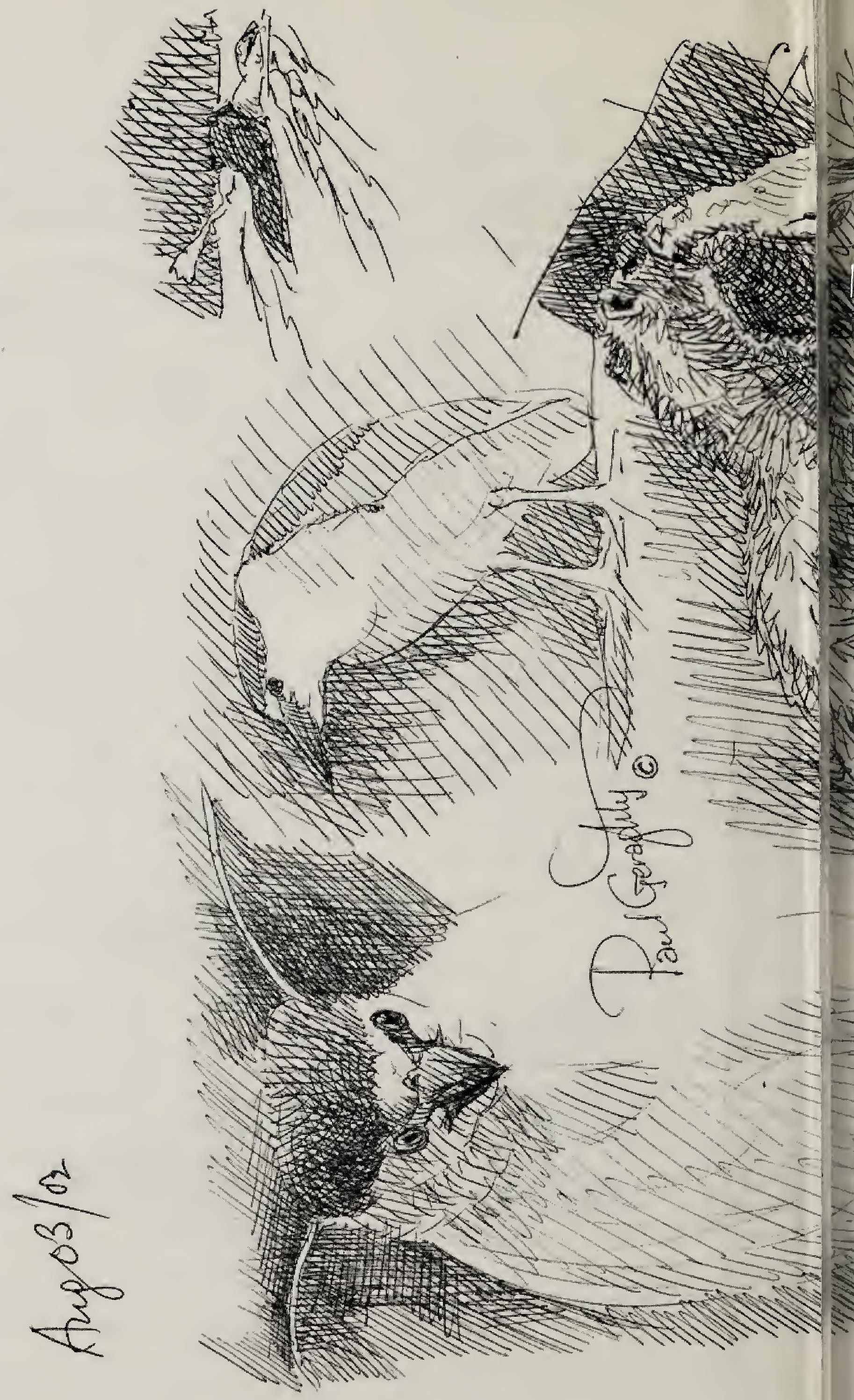




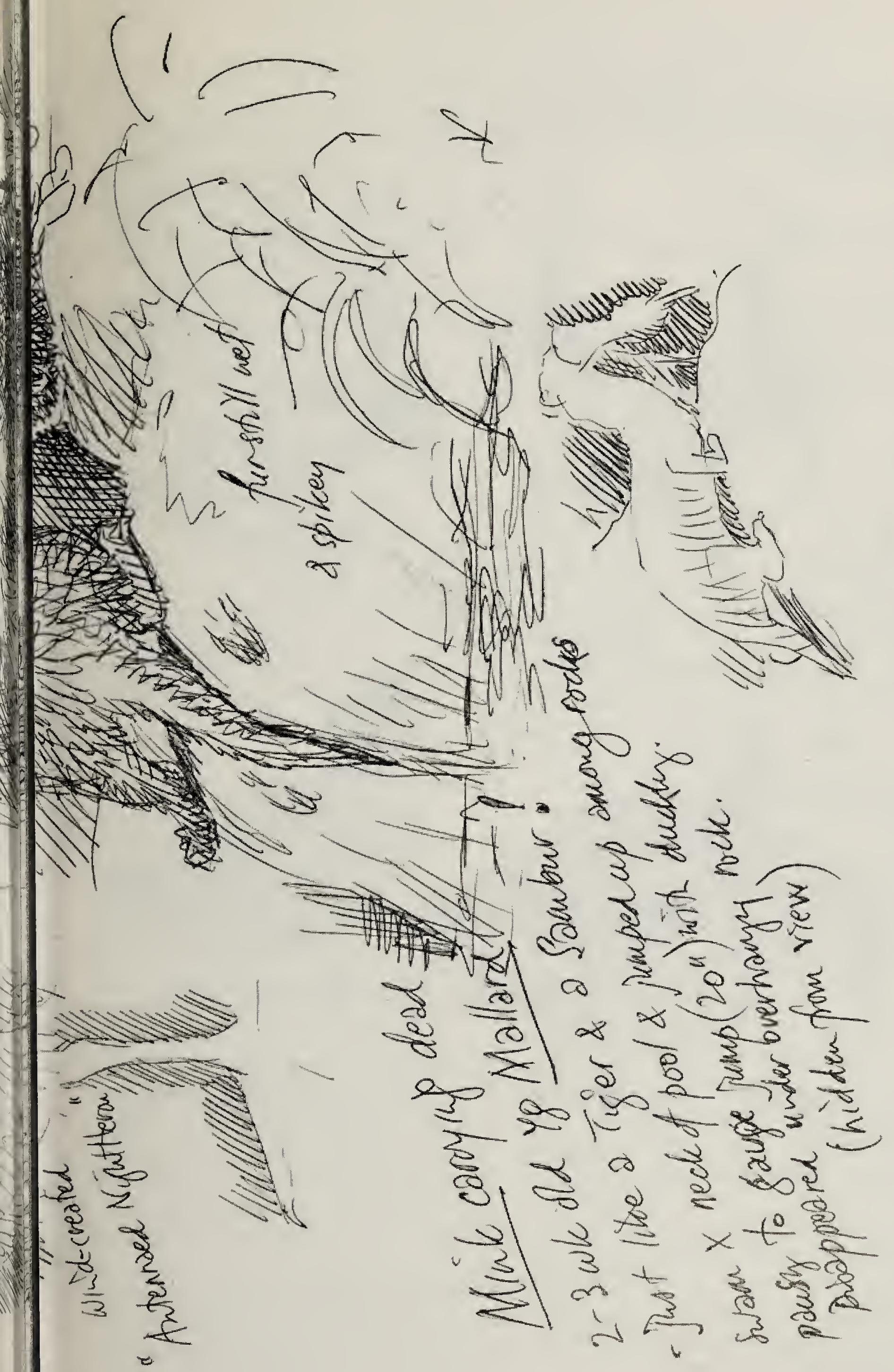




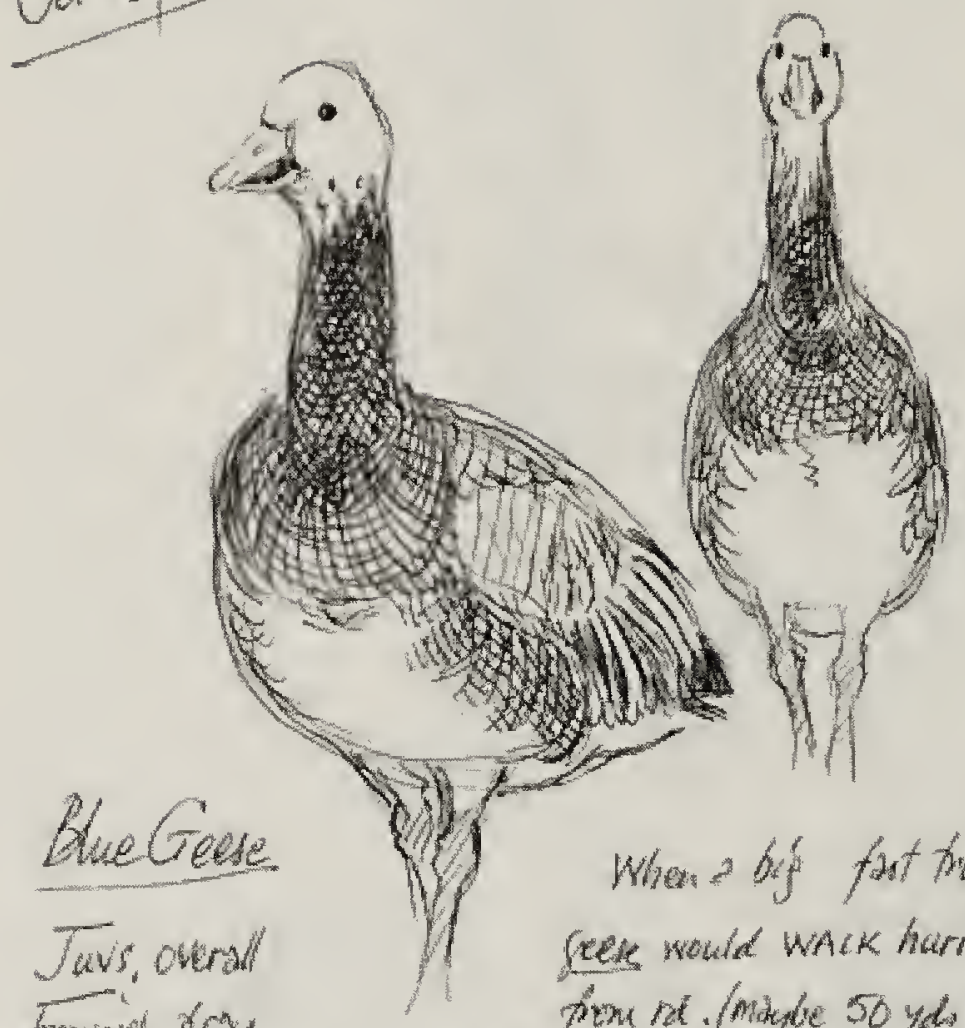

bowwish ordy.

from rad. (matabe 50 yes off) Head riecte-sooty-loobed like had been

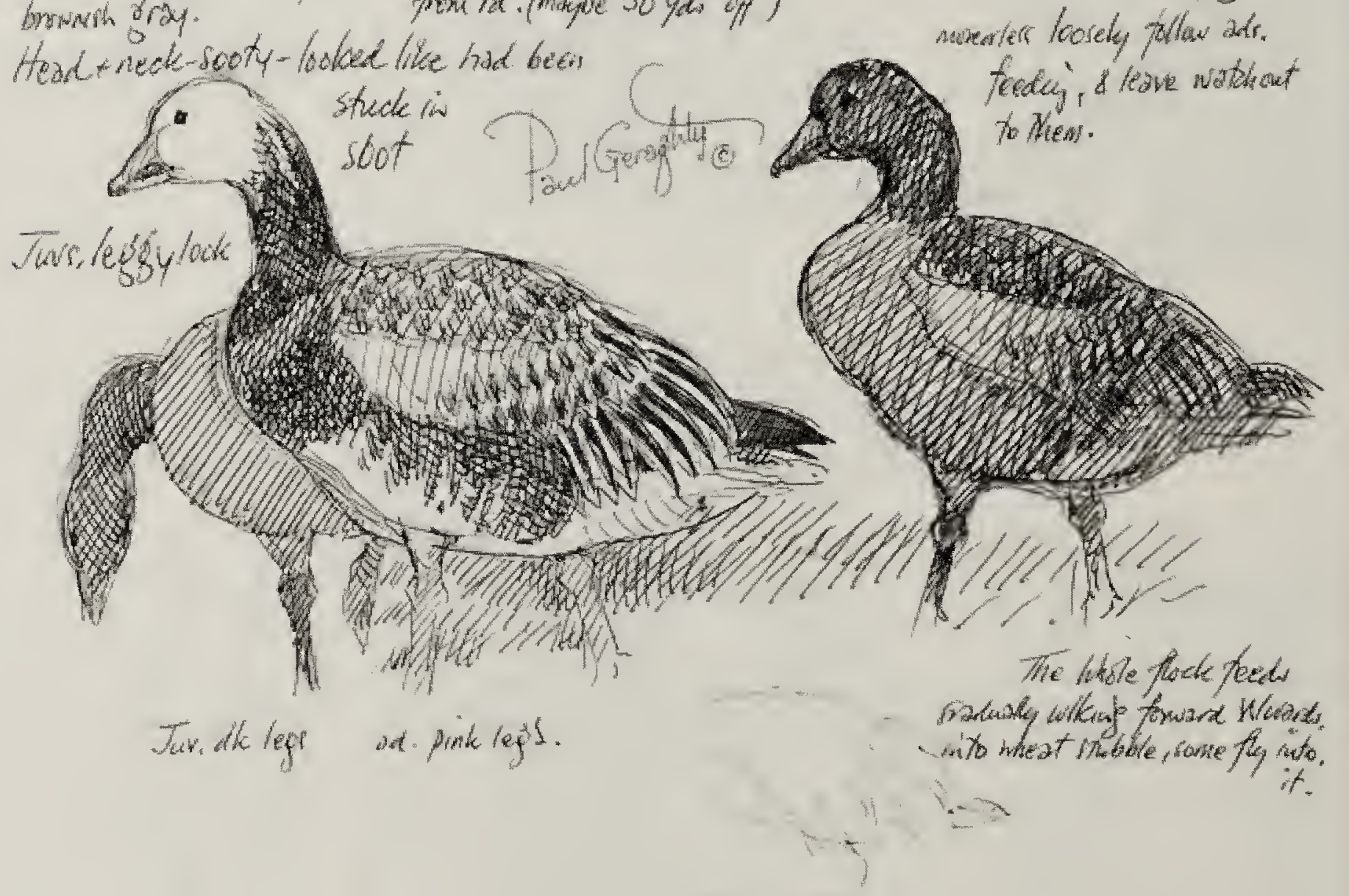

frequenth stanc to ath

8 you hinke Rercis on atam lat fraketh it diume that they are maintaring their feromal/fomily'zones'

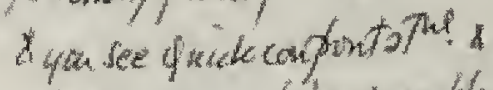

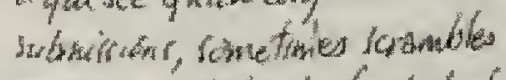
bue ove for 4 thet
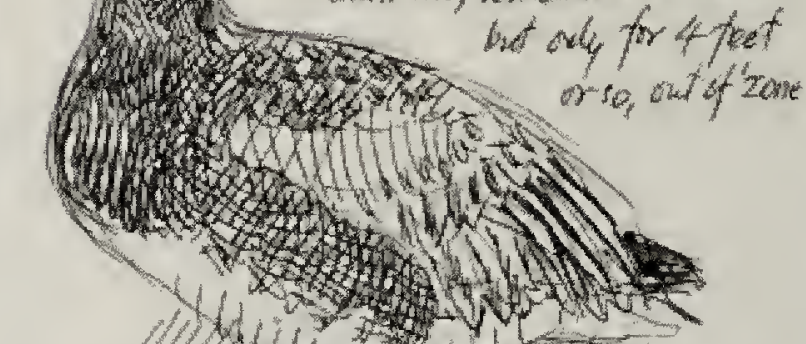

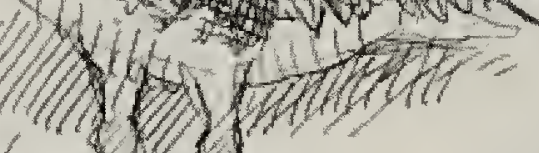
cime by,

11

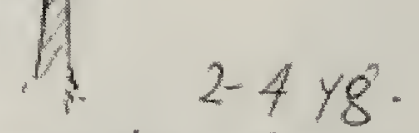

moververt loosely follow ats. 